\title{
PERSPECTIVES
}

\section{TITLE: The AHK-Wales Report Card 2018: Policy Measures - Is it possible to 'score' qualitative data?}

\author{
Malcolm R Ward ${ }^{1}$, Richard Tyler ${ }^{2}$, Lowri C Edwards ${ }^{3}$, Maggie C Miller $^{4}$, Simon \\ Williams $^{5}$, Gareth Stratton ${ }^{1,6}$
}

1. School of Sport and Exercise Science, College of Engineering, Swansea University; Bay Campus, Fabian Way, Swansea, SA1 8EN, Wales, UK.

2. Health Research Institute and Department of Sport and Physical Activity, Edge Hill University; St Helens Road, Ormskirk, Lancs, L39 4QP, England, UK.

3. Cardiff School of Sport and Health Sciences, Cardiff Metropolitan University; Cyncoed Campus, Cyncoed Road, Cardiff, CF23 6XD, Wales, UK.

4. School of Management, Swansea University; Bay Campus, Fabian Way, Swansea, SA1 8EN, Wales, UK.

5. University of Wales Trinity St David; Carmarthen Campus, SA31 2NL, Wales, UK.

6. Applied Sports Technology Exercise and Medicine (A-STEM) Research Centre, College of Engineering, Swansea University; Bay Campus, Fabian Way, Swansea, SA1 8EN, Wales, UK.

Corresponding Authors: Prof. Gareth Stratton, (+44)01792606544, g.stratton@swansea.ac.uk; Dr. Richard Tyler, (+44)01695584842, Tylerr@edgehill.ac.uk; Malcolm Ward, (+44)07952341587, malcolmward@ntlworld.com.

Word Count: 5,704 words (3,195 words for body of text; 243 words for abstract; 847 words for tables; 1,038 words for references; 381 words for supplementary material) 


\section{ACKNOWLEDGEMENTS:}

With thanks for all the advice and support from Dr Sonja Kahlmeier, University of Zurich and HEPA Europe, and the Active Healthy Kids Wales Expert Group 2018 including: Mr Dylan Blain, University Wales Trinity Saint David; Dr Anna Bryant, Cardiff Metropolitan University; Mr Neil Canham, Sustrans; Ms Lauren Carter-Davies, Sport Wales; Dr Cain Clark, Coventry University; Mr Tim Evans, Sport Wales; Ms Ceri Greenall, Welsh Government; Ms Julie Hobday, County Youth Dance Company; Dr Anwen Jones, Cardiff Metropolitan University; Ms Marianne Mannello, Play Wales; Ms Emily Marchant, Swansea University; Dr Graham Moore, Cardiff University; Dr Kelly Morgan, Cardiff University; Professor Sarah Nicholls, Swansea University; Mr Chris Roberts, Welsh Government; Mr Mike Sheldrick, Swansea University; Ms Karen Thompson, Public Health Wales; Dr Nalda Wainwright, University Wales Trinity Saint David.

\section{FUNDING:}

The Active Healthy Kids Wales 2018 Report Card was developed through in-kind contributions from the Wales Active Healthy Kids Advisory Group. Work was also supported by a grant from The Waterloo Foundation. 


\title{
PERSPECTIVES
}

\section{TITLE: The AHK-Wales Report Card 2018: Policy Measures - Is it possible to 'score' qualitative data?}

Word Count: 5,704 words (3,195 words for body of text; 243 words for abstract; 847 words for tables; 1,038 words for references; 381 words for supplementary material)

\begin{abstract}
Comprehensive and meaningful policy analysis in the field of physical activity is difficult, not least because of the variable influence of other policy domains. However, in 2011 a Policy Assessment Tool (PAT) was developed by members of the WHO European Network for the Promotion of Health-Enhancing Physical Activity (HEPA Europe) and tested in several different countries. In 2014, Wales joined a global initiative, Active Healthy Kids (AHK) Global Alliance, that supported the development of country level 'Report Cards' scoring a range of indicators that influence physical activity amongst children and young people, one of which was labelled 'Government Strategies and Investments'. For the first two Report Cards this indicator and its associated 'score' was informed subjectively by expert consensus. In 2018, it was decided to utilise the Policy Audit Tool Version 2 (PAT v2) developed by HEPA Europe to aid analysis and to develop and test a scoring rubric aligned to the tool. The subsequent process indicated that the tool could be applied and translated into a 'grade' that could be used in conjunction with the other indicators of the AHK Report Card to generate overall Report Card grades. The use of both the HEPA PAT v2 and the scoring rubric offers an opportunity to provide greater consistency and potential for developing both comparative and trend data when assessing policy impact on physical activity in children and young people. These tools should be utilised by the AHK Global Alliance in future Report Cards.
\end{abstract}


Key words: Physical Activity; Policy; Assessment; Active Healthy Kids

\section{INTRODUCTION}

Sufficient physical activity is widely accepted as an effective preventative measure for a variety of health risks and non-communicable diseases across all subgroups (e.g. age, sex, ethnicity, and socio-economic) (Department of Health, 2011; World Health Organisation, 2018). Further, adequate levels of physical activity in childhood can: i) improve childhood health status, leading to healthy growth and development (Andersen, Riddoch, Kriemler, \& Hills, 2011; Biddle \& Asare, 2011; Boreham \& McKay, 2011; Janssen \& Leblanc, 2010), ii) result in improved adult health status (Lee et al., 2012; Warburton, Charlesworth, Ivey, Nettlefold, \& Bredin, 2010), and iii) enable the formation of healthy behaviours that may be carried into adulthood and across the life course (Boreham \& Riddoch, 2001; Kelly et al., 2007; Telama, 2009; Telama et al., 2014). The Lancet series on Physical Activity (Bauman et al., 2012; Guthold, Stevens, Riley, \& Bull, 2018; Hallal et al., 2012; Kohl et al., 2012; Sallis et al., 2016), advocated that "optimal physical activity monitoring and surveillance should focus on physical activity levels and behaviours, their determinants and outcomes, and indicators of proven and promising solutions to address low physical activity in various segments of the population." Specifically, it is suggested that measuring overall physical activity is not adequate for policy and intervention development (Bauman et al., 2012; Hallal et al., 2012; Kohl et al., 2012; Sallis et al., 2016). Instead, physical activity levels and behaviours, their determinants and outcomes should be the focus, and trends in physical activity across multiple domains should be monitored at the individual, social, environmental, and societal levels (Bauman et al., 2012; Hallal et al., 2012; Kohl et al., 2012; Sallis et al., 2016). Furthermore, a thorough and critical evaluation is needed for all sectors and settings that have a known impact on physical activity levels, including school, community, and in particular government policy, 
strategies and investment. With this objective, the Active Healthy Kids (AHK) Global Alliance country Report Card series on physical activity, uses national surveillance data under key indicators to analyse physical activity behaviours, settings, and influences in children and young people (Tremblay et al., 2014).

Originally developed in Canada (Active Healthy Kids Canada, 2005), the 'AHK Global Matrix' is now an international initiative based on bi-annual 'Report Cards' from 49 countries (Aubert et al., 2018). It was established by the AHK Global Alliance in 2014 (https://www.activehealthykids.org/) following the success of the first Global Summit on the Physical Activity of Children in Toronto (Tremblay, 2014; Tremblay et al., 2014). The 'Report Card' is a tool with a common structure that uses a set of nine core physical activity indicators covering the key components that influence the potential to promote physical activity in children and young people at a national level. These indicators include: Overall Physical Activity; Organised Sport and Physical Activity; Active Play; Active Transportation; Sedentary Behaviours; Family and Peers; School; Community and the Built Environment; and Government Strategies and Investments. Each indicator has one or more benchmarks represented by a percentage (e.g. \% of children and youth who meet sedentary behaviour or screen-time guidelines). An agreed grading matrix is then used to assign a grade against each indicator that ranges from A (excellent) to F (failing) (Edwards et al., 2018; Stratton, Edwards, \& Tyler, 2018). Whilst this approach is still open to bias, the quantitative metrics provide a generally consistent method of evaluating and grading the evidence in relation to key indicators of children and young people's physical activity at a national level, and, if applied consistently, can be used to indicate trends over time. However, the indicator related to 'Government Strategies and Investments' does not have meaningful quantitative metrics that can be applied to assess policies and strategies and thus has been reliant on a 'grade' determined by general 
consensus of the expert groups within the countries that develop the Report Cards.

Wales has been a member of the AHK Global Alliance since its establishment in 2014 and has produced three biannual Report Cards to date (Stratton et al., 2016, 2014; Tyler et al., 2016). The first two Report Cards relied on expert consensus to score the 'Government Strategies and Investments' indicator, following group discussion on the range and relevance of national policies and investments related to physical activity and children/young people. Although a recent review has identified increasing numbers of studies in the field of physical activity policy research that have used a variety of methods for policy analysis (Pogrmilovic, O'sullivan, Milton, Biddle, \& Pedisic, 2019), there have been very few validated tools to aid such work (Pogrmilovic et al., 2019). A Policy Analysis Framework was published in 2002 and whilst it paved the way, it was at an early stage of physical activity policy development and was limited in the range of contributing sectors identified in the Framework (Schmid, Pratt, \& Witmer, 2006). However, these limitations were largely addressed by the development of the Health Enhancing Physical Activity (HEPA) Policy Audit Tool (PAT) (Bull, Milton, \& Kahlmeier, 2015), developed by the national approaches working group of the WHO HEPA Europe network (http://www.euro.who.int/en/health-topics/disease-prevention/physicalactivity/activities/hepa-europe) that provided a framework covering all the policy domains that informed the report card. This tool provides a structured framework that is informed by experts, internationally tested and potentially transferable. Version 1 of the HEPA PAT was launched in 2011 by the HEPA Europe network (Bull, Milton, \& Kahlmeier, 2011), and subsequently updated with Version 2 in 2015 (Bull et al., 2015). The tool covers: Context, Leadership, Partnership, Policies, Recommendations, Surveillance, Evaluation, Funding, Networks and Experiences amongst other areas. Further, the tool offers a valuable way of collating the relevant information, providing useful prompts, and a structure that aided subsequent analyses. 
Therefore, the Health Enhancing Physical Activity Policy Audit Tool Version 2 (HEPA PAT v2) was used to analyse the 'Government Strategies and Investments' indicator in the Wales' AHK 2018 Report Card (Edwards et al., 2018; Stratton et al., 2018). The aim of this paper was to describe the process taken to analyse and measure the potential of national policies, strategies and legislative instruments in influencing population physical activity using the HEPA PAT v2 and a locally developed 'scoring rubric'.

\section{METHODS}

An expert, multi-agency, multidisciplinary working group was established and led by one of the authors of this paper. The group included researchers and academics, national policy advisors and specialist practitioners from national organisations. These included: i) academics from seven Universities with research expertise in a variety of physical activity settings, ii) practitioners and policy advisors from national institutions representing public health, sport, play, dance and active travel, and iii) researchers and policy advisors from the national government. Sub-groups were established to develop and assess each of the indicators and members met monthly to share information, update colleagues, discuss issues and gain consensus wherever possible.

Using the HEPA PAT v2 (Bull et al., 2015) the 'Government Strategies and Investments' sub-group identified twenty one relevant policy instruments including action plans, national guidelines and legislation that covered the spectrum of physical activity in children and young people in Wales. Policy areas included health, sport and recreation, education, transport, environment, urban design and planning, play, sustainable development and cross-cutting (Supplementary Material 1). Each of these were analysed to identify explicit actions; lines of accountability; reporting structures; monitoring and evaluation; central funding and alternative resourcing (e.g. redistribution, allocation or prioritisation of funding 
from associated shared sums of money such as local authority allocations for children's services/transport, and the establishment of national programmes such as the ' 10 steps to a healthy weight' programme that provides a range of both virtual and actual support materials). Actions included in policies were qualitatively analysed and a narrative was developed against all the indicators. The HEPA PAT v2 provided a useful framework for identifying the key strengths, weaknesses and opportunities afforded by the existing physical activity policy environment but did not provide a quantitative 'score' for this element of the AHK Report Card.

To address the absence of a quantitative score, a 'scoring rubric' was developed and aligned to criteria informed by 'prompts' provided by the HEPA PAT v2. The eleven HEPA PAT v2 sections covered all aspects of policy development, implementation and evaluation and in the process stimulates consideration of a number of critical factors that influence the likely effectiveness of the policy. Whilst applying the tool it became evident that from these 'prompts' it was possible to identify six key criteria that were both likely to be influential in developing policy drivers that could translate into effective actions and at the same time had the potential to be quantified. Table 1 presents the key criteria extrapolated from the HEPA PAT v2.

\section{[INSERT TABLE 1 ABOUT HERE]}

It was acknowledged that no single criteria would be effective in isolation and that some carried greater potential influence than others, and so consideration was given to the respective influence of each of the criteria. As the indicators within the AHK Report Card were scored by percentages that aligned to 'grades' (Aubert et al., 2018), it was acknowledged that a similar 
scoring system would need to be developed for the 'Government Strategies and Investments' indicator. The sub-group responsible for this indicator conferred and agreed the relative importance of each of the criteria based on their personal and professional expertise. Subsequently, a percentage weighting was applied to each criterion that reflected its relative importance as a contributor to the total (100\%) score. For example, 'Accountability' was identified as being more important than the 'Number of Policies'. Having agreed the weighting within the sub-group, the proposal was then taken to the wider expert group and following further consideration a final scoring rubric was agreed (see Table 2). The six agreed criteria extrapolated from the PAT sections, and their respective weighting scores, were:

i. Number and Breadth of Relevant Policies - 10\% (5\% Number \& 5\% Breadth): The number and breadth of policies was deemed to be of less importance than their content. There is some evidence that those countries with the most policies often have amongst the worst levels of physical activity (Guthold et al., 2018).

ii. Identified Supporting Actions - 20\%: It was felt that implementation of meaningful and specific actions was significantly more important than the number of policies.

iii. Identified Accountable Organisation - 25\%: Accountability was deemed to be the most important factor in delivering effective physical activity policy. One weakness identified in the analysis of the AHK-Wales 2018 Report Card was the lack of clarity of where the responsibility lay for effective delivery, an issue previously reported by the Wales Audit Office (Wales Audit Office, 2007).

iv. Identifiable Reporting Structures - 15\%: Allied to accountability was the recognition of the need for clear and transparent reporting structures which were too often missing from many of the policy instruments analysed, this had also been previously highlighted (Wales Audit Office, 2007). 
v. Identified Funding - 20\% (5\% number of identified national programmes \& $15 \%$ funding): This was highlighted as a major factor likely to have significant impact on the feasibility of delivering meaningful actions in support of policy. Recognising that physical activity is largely influenced by the environment in which it takes place, creating active communities or other settings will generally require significant additional investment. However, it was recognised that whilst funding was likely to be the most important and effective resource for remodelling systems or structures, there are other resources that may be influential including increasing operational synergies between delivery partners and establishing evidence-based programmes, using behaviour change techniques and social marketing tools within settings, or targeting population groups (Global Advocacy for Physical Activity (GAPA) the Advocacy Council of the International Society for Physical Activity and Health (ISPAH), 2011).

vi. Monitoring and Evaluation Plan - 10\%: Although monitoring and evaluation will not directly influence the effectiveness of policies that support physical activity, they are critical in establishing a baseline and for understanding the process of policy implementation. Without this it would be impossible to know whether the policies are having the desired effect, to what extent and how? Implicit in this is the need for good, robust, regular data which was another weakness identified in the Wales Audit Office report (Wales Audit Office, 2007).

\section{[INSERT TABLE 2 ABOUT HERE]}

Using this scoring rubric (Table 2), weighting scores were ascribed to each of the criteria that in turn generated a total percentage score that was subsequently converted using the AHK Global Alliance grading rubric (Aubert et al., 2018; Stratton et al., 2018). For 
example, there were many policy instruments covering a wide range of physical activity determinants and so the group assigned a score of 9 from a possible 10 for the "Number \& breadth of relevant policies" criteria. The remaining criteria were similarly scored relative to their weighting. All scores were then further considered, refined and agreed by the expert group to produce an overall 'Government Strategies and Investments' grade (ranging from A (excellent) to F (failing)) for the AHK-Wales 2018 Report Card.

\section{RESULTS}

Twenty-one policy instruments covering nine key policy domains relevant to physical activity in Wales were identified and analysed against the six criteria. Of these, fourteen included identifiable supporting actions; fifteen had identified accountable organisations although six of these only ascribed 'accountability' to one organisation or sector (e.g. Local Authority); seven had formal reporting mechanisms; five had a monitoring and evaluation plan and five had identified specific funding (Supplementary Material 1). However, even where funding wasn't specifically identified, a number of national policy instruments were supported through alternative resourcing mechanisms such as lottery funding or other grant schemes. The working group identified nine such instruments as evidence of national "resources" geared towards increasing physical activity outcomes. These included three that were unique to Wales including an Active Travel Act, the Well-being of Future Generations Act and a national Play Strategy where Wales became the first country to adopt UN action 31 recognising the rights of the child (Supplementary Material 2). Each of these nine policy instruments could be seen as promoting physical activity opportunities for children, either then or in the foreseeable future, and so were factored into the score for the sub-domain 'Identified Funding and Resources'. With use of the locally developed scoring rubric, the final criteria for the 'Government Strategies and Investments' indicator are presented in Table 3. 


\section{[INSERT TABLE 3 ABOUT HERE]}

Overall, the scoring rubric provided a cumulative score of $54 \%$ that translates into a $\mathrm{C}+$ grade on the Report Card grading rubric for 2018 (Aubert et al., 2018). An interesting observation was that this more 'quantitative' score was actually very close to the previous (2016) score of B- that was awarded on the basis of a wholly subjective general consensus. This suggests that expert consensus is comparable to more quantitative approaches as well as reassuring the group that the scoring and weighting system was reasonably accurate.

\section{DISCUSSION}

The launch of the World Health Organisation Global Action Plan for Physical Activity (World Health Organisation, 2018) once again focuses on the effectiveness of policy instruments in affecting change in the field of physical activity. Despite a plethora of policies, strategies, action plans, guidance documents and Report Cards at international, national and sub-national levels, recommended physical activity in most parts of the world remains intractably low (Rütten, Abu-Omar, Gelius, \& Schow, 2013). Whilst specific physical activity policies may have been evaluated, the range and complexity of physical activity determinants makes a comprehensive assessment of contributing policies more difficult. The HEPA PAT v2 (Bull et al., 2015), offered an effective and simple framework for analysing the full range of policy influences in this arena.

The AHK-Wales 2018 Report Card (Edwards et al., 2018; Stratton et al., 2018), provided an ideal opportunity to test the HEPA PAT v2 but also provided the additional challenge of not only subjectively appraising the policy influences but also assigning a specific quantitative 'score' at the end of the process. The tool provided a useful framework on which 
to develop a scoring rubric and, when applied, this compared favourably with the less quantitative 'estimations' of previous iterations of the Report Card as it was applied in Wales. This would suggest that this dimension of physical activity could potentially be 'measured' and compared both over time and between users when the tool is applied consistently. Pogrmilovic et al. (2019), noted both the need for the development of standardised methods for physical activity policy analysis and the relative disproportion of engagement of low- and middle-income countries. Whilst this paper outlines one approach taken in Wales the authors acknowledge the methodological limitations of the system that they have developed for quantifying what is a complex and largely qualitative process. We do however believe it could provide a useful contribution to addressing these conceptually challenging problems. The scoring rubric and associated weighting was developed through consensus amongst a small group of experts and will certainly need wider critical consideration and testing to establish global agreement and acceptability. The AHK Global Alliance and associated report cards has now become widely established with a significant global reach that includes countries in all socio-economic groups which does provide an opportunity for the development and testing of innovative approaches. We hope to use this network of diverse alliances with common aims, to work collaboratively in refining tools that could ultimately meet the needs of all users and provide the consistency of analysis that has so far proven so elusive.

Initiatives such as the AHK Report Card series can be useful for measuring and comparing different aspects of physical activity, however, they are less a means of establishing and monitoring hard metrics than as an advocacy tool. In that respect, the 'Government Strategies and Investments' section of the tool is of particular importance especially when paired with the more quantitative data provided through the rest of the tool. It is important, therefore, that the final 'score' is as robust as can be expected but also supported by a comprehensive and consistent descriptive analysis, such as can be provided by the HEPA PAT 
v2. Applying a score is less of an issue when simply auditing or analysing policy, so a scoring rubric is of little value for a one-off audit. However, if there is an intention to monitor the effectiveness of policy over time then this can be a useful adjunct to help measure progress or lack of it.

\section{CONCLUSION}

The Health-Enhancing Physical Activity Policy Audit Tool Version 2 provided a useful framework for analysing physical activity policy instruments that informed the AHK-Wales 2018 Report Card, and when allied to a scoring rubric allows a credible score to be applied even where the data is largely qualitative. The use of both the HEPA PAT v2 and the scoring rubric offers an opportunity to provide greater consistency and potential for developing both comparative and trend data when assessing policy impact on physical activity in children and young people. These tools should be utilised by the AHK Global Alliance in future Report Cards.

\section{RECOMMENDATIONS}

It is recommended that both the HEPA PAT v2 and the associated scoring rubric are applied by all countries participating in the AHK Global Alliance when preparing the 'Government Strategies and Investments' section of the Report Card. It is further recommended that the tool is used for at least 3 iterations of the Report Card and evaluated for acceptability, consistency and impact. 
Accepted: 28/09/2020 - Health Promotion International - Manuscript ID: HPI-2019-156.R1

\section{TABLE CAPTIONS:}

Table 1. Key Criteria Extrapolated from HEPA PAT v2

Table 2. Scoring Rubric

Table 3. AHK-Wales 2018 - Government: Scoring Grid 
Accepted: 28/09/2020 - Health Promotion International - Manuscript ID: HPI-2019-156.R1

\section{REFERENCES:}

Active Healthy Kids Canada. (2005). Dropping the ball: Canadas Report card on Physical Activity for Children \& Youth. Retrieved from https://participaction.cdn.prismic.io/participaction\%2F146e31ed-4a44-47cf-8925a5774b5a7290_participaction-2005-report-card-droppingtheball-highlight.pdf

Andersen, L. B., Riddoch, C., Kriemler, S., \& Hills, A. (2011). Physical activity and cardiovascular risk factors in children. British Journal of Sports Medicine, 45(11), 871876. https://doi.org/10.1136/bjsports-2011-090333

Aubert, S., Barnes, J. D., Abdeta, C., Abi Nader, P., Adeniyi, A. F., Aguilar-Farias, N., ... Tremblay, M. S. (2018). Global Matrix 3.0 Physical Activity Report Card Grades for Children and Youth: Results and Analysis From 49 Countries. Journal of Physical Activity and Health, 15(S2), S251-S273. https://doi.org/10.1123/jpah.2018-0472

Bauman, A. E., Reis, R. S., Sallis, J. F., Wells, J. C., Loos, R. J. F., Martin, B. W., ... Sarmiento, O. L. (2012). Correlates of physical activity: Why are some people physically active and others not? The Lancet, 380(9838), 258-271. https://doi.org/10.1016/S0140-6736(12)60735-1

Biddle, S. J. H., \& Asare, M. (2011). Physical activity and mental health in children and adolescents: A review of reviews. British Journal of Sports Medicine, 45(11), 886-895. https://doi.org/10.1136/bjsports-2011-090185

Boreham, C., \& McKay, H. A. (2011). Physical activity in childhood and bone health. British Journal of Sports Medicine, 45(11), 877-879. https://doi.org/10.1136/bjsports-2011090188

Boreham, C., \& Riddoch, C. (2001). The physical activity, fitness and health of children. Journal of Sports Sciences, 19(12), 915-929. https://doi.org/10.1080/026404101317108426 
Bull, F., Milton, K., \& Kahlmeier, S. (2011). Health-enhancing physical activity (HEPA) Policy Audit Tool (PAT). Copenhagen, Denmark: WHO Regional Office for Europe.

Bull, F., Milton, K., \& Kahlmeier, S. (2015). Health-enhancing physical activity (HEPA) Policy Audit Tool (PAT) - version 2. Copenhagen, Denmark: WHO Regional Office for Europe.

Department of Health. (2011). Start Active, Stay Active: A report on physical activity from the four home countries' Chief Medical Officers.

https://doi.org/https://www.gov.uk/government/uploads/system/uploads/attachment_data /file/216370/dh_128210.pdf

Edwards, L. C., Tyler, R., Blain, D., Bryant, A., Canham, N., Carter-Davies, L., ... Stratton, G. (2018). Results From Wales' 2018 Report Card on Physical Activity for Children and Youth. Journal of Physical Activity and Health, 15(S2), S430-S432.

https://doi.org/10.1123/jpah.2018-0544

Global Advocacy for Physical Activity (GAPA) the Advocacy Council of the International Society for Physical Activity and Health (ISPAH). (2011). NCD Prevention: Investments that Work for Physical Activity. Retrieved from www.globalpa.org.uk/investmentsthatwork

Guthold, R., Stevens, G. A., Riley, L. M., \& Bull, F. C. (2018). Worldwide trends in insufficient physical activity from 2001 to 2016: a pooled analysis of 358 populationbased surveys with 1.9 million participants. The Lancet Global Health, 6(10), e1077e1086. https://doi.org/10.1016/S2214-109X(18)30357-7

Hallal, P. C., Andersen, L. B., Bull, F. C., Guthold, R., Haskell, W., Ekelund, U., ... Wells, J. C. (2012). Global physical activity levels: Surveillance progress, pitfalls, and prospects. The Lancet, 380(9838), 247-257. https://doi.org/10.1016/S0140-6736(12)60646-1 Janssen, I., \& Leblanc, A. G. (2010). Systematic review of the health benefits of physical 
Accepted: 28/09/2020 - Health Promotion International - Manuscript ID: HPI-2019-156.R1

activity and fitness in school-aged children and youth. The International Journal of Behavioral Nutrition and Physical Activity, 7, 40. https://doi.org/10.1186/1479-5868-740

Kelly, L. A., Reilly, J. J., Jackson, D. M., Montgomery, C., Grant, S., \& Paton, J. Y. (2007). Tracking physical activity and sedentary behavior in young children. Pediatric Exercise Science, 19(1), 51-60. https://doi.org/10.1123/pes.19.1.51

Kohl, H. W., Craig, C. L., Lambert, E. V., Inoue, S., Alkandari, J. R., Leetongin, G., ... Wells, J. C. (2012). The pandemic of physical inactivity: Global action for public health. The Lancet, 380(9838), 294-305. https://doi.org/10.1016/S0140-6736(12)60898-8

Lee, I. M., Shiroma, E. J., Lobelo, F., Puska, P., Blair, S. N., Katzmarzyk, P. T., ... Wells, J. C. (2012). Effect of physical inactivity on major non-communicable diseases worldwide: An analysis of burden of disease and life expectancy. The Lancet, 380(9838), 219-229. https://doi.org/10.1016/S0140-6736(12)61031-9

Pogrmilovic, B. K., O’sullivan, G., Milton, K., Biddle, S. J. H., \& Pedisic, Z. (2019). A systematic review of instruments for the analysis of national-level physical activity and sedentary behaviour policies. Health Research Policy and Systems, 17(1), 1-12. https://doi.org/10.1186/s12961-019-0492-4

Rütten, A., Abu-Omar, K., Gelius, P., \& Schow, D. (2013). Physical inactivity as a policy problem: Applying a concept from policy analysis to a public health issue. Health Research Policy and Systems, 11(1), 1-9. https://doi.org/10.1186/1478-4505-11-9

Sallis, J. F., Bull, F., Guthold, R., Heath, G. W., Inoue, S., Kelly, P., ... Hallal, P. C. (2016). Progress in physical activity over the Olympic quadrennium. The Lancet, 388(10051), 1325-1336. https://doi.org/10.1016/S0140-6736(16)30581-5

Schmid, T. L., Pratt, M., \& Witmer, L. (2006). A Framework for Physical Activity Policy Research. Journal of Physical Activity and Health, 3(s1), S20-S29. 
Accepted: 28/09/2020 - Health Promotion International - Manuscript ID: HPI-2019-156.R1

https://doi.org/10.1123/jpah.3.s1.s20

Stratton, G., Cox, R., Mannello, M., Mattingley, R., Robert, C., Sage, R., ... Future. (2016).

Is Wales Turning the Tide on Children's Inactivity? Active Healthy Kids Wales 2016

Report Card. Swansea, U.K.

Stratton, G., Edwards, L., \& Tyler, R. (2018). Active Healthy Kids - Wales 2018 Report.

Retrieved from http://senedd.assembly.wales/documents/s76266/Active Healthy Kids

Wales 2018 Report.pdf

Stratton, G., Williams, C., Taylor, S., Jones, A. M., Mackintosh, K., Frost, M., ... Williams, S. (2014). Active Healthy Kids Report Card - Wales 2014. Swansea, U.K.

Telama, R. (2009). Tracking of Physical Activity from Childhood to Adulthood: A Review. Obesity Facts, 2(3), 187-195. https://doi.org/10.1159/000222244

Telama, R., Yang, X., Leskinen, E., Kankaanpää, A., Hirvensalo, M., Tammelin, T., ... Raitakari, O. T. (2014). Tracking of physical activity from early childhood through youth into adulthood. Medicine and Science in Sports and Exercise, 46(5), 955-962. https://doi.org/10.1249/MSS.0000000000000181

Tremblay, M. S. (2014). 2014 Global Summit on the Physical Activity of Children. Journal of Physical Activity and Health, 11(s1), S1-S2. https://doi.org/10.1123/jpah.2014-0182

Tremblay, M. S., Gray, C. E., Akinroye, K., Harrington, D. M., Katzmarzyk, P. T., Lambert, E. V., ... Tomkinson, G. (2014). Physical Activity of Children: A Global Matrix of Grades Comparing 15 Countries. Journal of Physical Activity and Health, 11(s1), S113S125. https://doi.org/10.1123/jpah.2014-0177

Tyler, R., Mannello, M., Mattingley, R., Roberts, C., Sage, R., Taylor, S. R., ... Stratton, G. (2016). Results From Wales' 2016 Report Card on Physical Activity for Children and Youth: Is Wales Turning the Tide on Children's Inactivity? Journal of Physical Activity and Health, 13(11 Suppl 2), S330-S336. https://doi.org/10.1123/jpah.2016-0309 
Accepted: 28/09/2020 - Health Promotion International - Manuscript ID: HPI-2019-156.R1

Wales Audit Office. (2007). Increase Physical Activity. Cardiff, UK. Retrieved from http://www.wales.nhs.uk/documents/physical_activity_eng.pdf

Warburton, D. E. R., Charlesworth, S., Ivey, A., Nettlefold, L., \& Bredin, S. S. (2010). A systematic review of the evidence for Canada's Physical Activity Guidelines for Adults. https://doi.org/10.14288/1.0223098

World Health Organisation. (2018). Global action plan on physical activity 2018-2030: more active people for a healthier world. Geneva: World Health Organisation. 
Table 1. Key Criteria Extrapolated from HEPA PAT v2

\begin{tabular}{|c|c|}
\hline HEPA PAT v2 Sections & $\begin{array}{l}\text { AHK-Wales } 2018 \text { Report Card } \\
\text { 'Government' Criteria }\end{array}$ \\
\hline $\begin{array}{l}\text { Background information and country } \\
\text { context: Inc. Governance, structures, } \\
\text { organisations }\end{array}$ & Identifiable Reporting Structures \\
\hline $\begin{array}{l}\text { Leadership and partnerships: Inc. } \\
\text { National \& Subnational leadership and } \\
\text { collaborations. }\end{array}$ & Identified Accountable Organisation(s) \\
\hline $\begin{array}{l}\text { Policy Documents: Inc. Policies, Action } \\
\text { Plans, Strategies and Events shaping } \\
\text { physical activity promotion }\end{array}$ & Number and Breadth of Relevant Policies \\
\hline $\begin{array}{l}\text { Recommendations, goals and targets: Inc. } \\
\text { Recommendations for Physical Activity \& } \\
\text { Health, National Goals and Targets }\end{array}$ & Identified Supporting Actions \\
\hline $\begin{array}{l}\text { Surveillance: Inc. Surveillance \& } \\
\text { Monitoring Systems }\end{array}$ & \multirow[b]{2}{*}{ Monitoring and Evaluation Plan } \\
\hline $\begin{array}{l}\text { Evaluation: Inc. National and subnational } \\
\text { policies and action plans and economic } \\
\text { evaluations. }\end{array}$ & \\
\hline $\begin{array}{l}\text { Funding and commitments: Inc. National } \\
\text { and subnational funding in sectors and } \\
\text { delivering aspects of physical activity. }\end{array}$ & Identified Funding \\
\hline $\begin{array}{l}\text { Capacity-building through a national } \\
\text { network: Inc. any professional network or } \\
\text { system that links and/or supports } \\
\text { professionals. }\end{array}$ & \multirow[t]{2}{*}{$\begin{array}{l}\text { Addressed through supporting narrative for } \\
\text { the Government indicator. }\end{array}$} \\
\hline $\begin{array}{l}\text { Experience of policy implementation, } \\
\text { progress and remaining challenges: Inc. } \\
\text { Progress, challenges and suggestions. }\end{array}$ & \\
\hline $\begin{array}{l}\text { Summary of how the HEPA PAT was } \\
\text { completed: }\end{array}$ & $\begin{array}{l}\text { Not relevant to AHK Report Card/ Global } \\
\text { Alliance. }\end{array}$ \\
\hline
\end{tabular}


Table 2. Scoring Rubric

\begin{tabular}{|c|c|c|c|c|c|}
\hline Criterion & \multicolumn{4}{|c|}{ Scores } & $\begin{array}{l}\text { Maximum Total } \\
\text { Score }\end{array}$ \\
\hline \multirow[t]{2}{*}{$\begin{array}{c}\text { Number and } \\
\text { Breadth of } \\
\text { Relevant Policies }\end{array}$} & $\begin{array}{l}\text { Policy } \\
\text { Number }\end{array}$ & Score & $\begin{array}{c}\text { Policy } \\
\text { Breadth } \\
\text { (No. of } \\
\text { Sectors) }\end{array}$ & Score & \multirow{7}{*}{$10(5+5)$} \\
\hline & $20+$ & 5 & $10+$ & 5 & \\
\hline \multirow{5}{*}{$\begin{array}{l}\text { Policies/ } \\
\text { strategies/ action } \\
\text { plans that } \\
\text { reference physical } \\
\text { activity. }\end{array}$} & $15-19$ & 4 & $8-9$ & 4 & \\
\hline & $10-14$ & 3 & $6-7$ & 3 & \\
\hline & $5-9$ & 2 & $4-5$ & 2 & \\
\hline & $1-4$ & 1 & $1-3$ & 1 & \\
\hline & 0 & 0 & 0 & 0 & \\
\hline $\begin{array}{c}\text { Identified } \\
\text { Supporting } \\
\text { Actions }\end{array}$ & \multicolumn{2}{|c|}{$\begin{array}{l}\text { No. of Policies with } \\
\text { identifiable Actions }\end{array}$} & \multicolumn{2}{|c|}{ Score } & \\
\hline $\begin{array}{l}\text { Strategic } \\
\text { documents with } \\
\text { specific actions } \\
\text { that promote } \\
\text { physical activity }\end{array}$ & \multicolumn{2}{|c|}{$\begin{array}{l}\text { Actual number of } \\
\text { documents to } \\
\text { maximum of } 20\end{array}$} & \multicolumn{2}{|c|}{$0-20$} & 20 \\
\hline $\begin{array}{c}\text { Identified } \\
\text { Accountable } \\
\text { Organisation(s) }\end{array}$ & \multicolumn{2}{|c|}{$\begin{array}{l}\text { Proportion (\%) of } \\
\text { Policies with } \\
\text { Identified } \\
\text { Responsibilities for } \\
\text { delivery of Actions }\end{array}$} & \multicolumn{2}{|c|}{ Score } & \multirow{7}{*}{25} \\
\hline \multirow{6}{*}{$\begin{array}{c}\text { Discreet } \\
\text { organisations } \\
\text { specifically } \\
\text { identified as } \\
\text { responsible for } \\
\text { delivery of actions. }\end{array}$} & \multicolumn{2}{|c|}{$100 \%$} & \multicolumn{2}{|c|}{25} & \\
\hline & \multicolumn{2}{|c|}{$80 \%$} & \multicolumn{2}{|c|}{20} & \\
\hline & \multicolumn{2}{|c|}{$60 \%$} & \multicolumn{2}{|c|}{15} & \\
\hline & \multicolumn{2}{|c|}{$40 \%$} & \multicolumn{2}{|c|}{10} & \\
\hline & \multicolumn{2}{|c|}{$20 \%$} & \multicolumn{2}{|c|}{5} & \\
\hline & \multicolumn{2}{|c|}{0} & \multicolumn{2}{|c|}{0} & \\
\hline
\end{tabular}




\begin{tabular}{|c|c|c|c|}
\hline $\begin{array}{c}\text { Identifiable } \\
\text { Reporting } \\
\text { Structures }\end{array}$ & $\begin{array}{l}\text { Proportion (\%) of } \\
\text { Policies with } \\
\text { Identified Systems } \\
\text { for Reporting } \\
\text { Delivery of Actions }\end{array}$ & Score & \multirow{8}{*}{15} \\
\hline \multirow{7}{*}{$\begin{array}{l}\text { Strategic } \\
\text { documents with } \\
\text { explicit reporting } \\
\text { systems including } \\
\text { frequency and } \\
\text { format of reports }\end{array}$} & $100 \%$ & 15 & \\
\hline & $75 \%$ & 12.5 & \\
\hline & $67 \%$ & 10 & \\
\hline & $50 \%$ & 7.5 & \\
\hline & $33 \%$ & 5 & \\
\hline & $20 \%$ & 3 & \\
\hline & 0 & 0 & \\
\hline \multirow{7}{*}{$\begin{array}{l}\text { Explicit references } \\
\text { to funding to } \\
\text { support identified } \\
\text { actions }\end{array}$} & $\begin{array}{l}\text { Proportion }(\%) \text { of } \\
\text { Policies with } \\
\text { Identified Funding } \\
\text { Sources }\end{array}$ & Score & \multirow{7}{*}{20} \\
\hline & $100 \%$ & 20 & \\
\hline & $75 \%$ & 15 & \\
\hline & $50 \%$ & 10 & \\
\hline & $25 \%$ & 5 & \\
\hline & $10 \%$ & 2 & \\
\hline & 0 & 0 & \\
\hline \multirow{7}{*}{$\begin{array}{l}\text { Explicit reference } \\
\text { to monitoring and } \\
\text { evaluation of } \\
\text { progress and } \\
\text { impact of the } \\
\text { policy }\end{array}$} & $\begin{array}{l}\text { Proportion }(\%) \text { of } \\
\text { Included Policies } \\
\text { with Identified } \\
\text { Systems for } \\
\text { Monitoring \& } \\
\text { Evaluation }\end{array}$ & Score & \multirow{7}{*}{10} \\
\hline & $100 \%$ & 10 & \\
\hline & $75 \%$ & 7.5 & \\
\hline & $50 \%$ & 5 & \\
\hline & $25 \%$ & 2.5 & \\
\hline & $10 \%$ & 1 & \\
\hline & 0 & 0 & \\
\hline
\end{tabular}


Table 3. AHK-Wales 2018 - Government: Scoring Grid

\begin{tabular}{|c|c|c|}
\hline Criteria & Narrative & Score \\
\hline $\begin{array}{l}\text { No. and breadth of } \\
\text { relevant policies }\end{array}$ & $\begin{array}{l}\text { In Wales, twenty-one national policies have been identified } \\
\text { that incorporate strategies, action plans, legislation and } \\
\text { guidance geared towards promoting physical activity in the } \\
\text { youth population of Wales. These policies emerge within, and } \\
\text { are implemented across, eight governmental domains } \\
\text { including Health, Sport, Education, Transport, Environment, } \\
\text { Planning, Play, and Sustainable Development. }\end{array}$ & 9/10 \\
\hline $\begin{array}{c}\text { Identified } \\
\text { supporting actions }\end{array}$ & $\begin{array}{l}\text { Thirteen of the twenty-one policies have identifiable actions } \\
\text { related to physical activity. Actions specific and relevant to } \\
\text { physical activity were limited across Welsh policies, as some } \\
\text { only allocated one supporting action or requirement, and } \\
\text { others have identified actions that are seemingly too broad } \\
\text { which made it difficult for the RWG to evaluate their } \\
\text { relevancy. }\end{array}$ & $13 / 20$ \\
\hline $\begin{array}{l}\text { Identified } \\
\text { accountable } \\
\text { organisation (s) }\end{array}$ & $\begin{array}{l}\text { Fourteen of the twenty-one policies have identified 'lead' } \\
\text { organisations, which are to support and take responsibility for } \\
\text { some of the identified physical activity policies and } \\
\text { provisions. }\end{array}$ & $17 / 25$ \\
\hline $\begin{array}{l}\text { Identifiable } \\
\text { reporting } \\
\text { structures }\end{array}$ & $\begin{array}{l}\text { Seven of the twenty-one Welsh policies have identified some } \\
\text { form of monitoring and reporting on their various policies and } \\
\text { related actions, albeit rarely in a structured way. }\end{array}$ & $5 / 15$ \\
\hline $\begin{array}{l}\text { Identified funding / } \\
\text { resourcing } \\
\text { (national } \\
\text { programmes) }\end{array}$ & $\begin{array}{l}\text { Eight of the twenty-one policies have identified funding to } \\
\text { support their identified actions. However, most of these were } \\
\text { referenced as 'identifying' or 'reviewing' funding } \\
\text { opportunities rather than directly providing evidence of } \\
\text { already allocated or dedicated provisions. As part of the } \\
\text { government's commitment to providing and promoting } \\
\text { physical activity in Wales, it has supported a number of } \\
\text { national programmes designed to increase physical activity } \\
\text { among children and young people. The RWG identified nine } \\
\text { of these programmes as evidence of national "resources" } \\
\text { geared towards increasing physical activity (PA) outcomes, } \\
\text { whereby each programme can be seen as a PA opportunity for } \\
\text { children, or a promotional initiative to encourage future PA } \\
\text { among this population. }\end{array}$ & $8 / 20$ \\
\hline
\end{tabular}




\begin{tabular}{|c|l|l|}
\hline & $\begin{array}{l}\text { Five of the twenty-one policies articulated an evaluation and } \\
\text { monitoring plan. Four of the five are mainstream policy areas } \\
\text { directly affecting physical activity (ie., Fairer Health } \\
\text { Outcomes For All: Reducing Inequities in Health Strategic } \\
\text { Action Plan Review; Getting Wales Moving; Climbing } \\
\text { Higher; and Creating an Active Wales). Additionally, it is } \\
\text { Month noting that of the various types of policy (e.g., } \\
\text { Evaluation Plan } \\
\text { legislation, strategy, action plan, guidance) that the RWG } \\
\text { identified for this indicator, all of the 'Action Plans' outlined } \\
\text { monitoring and evaluation strategies. Perhaps this is because } \\
\text { action plans are time bound and generally tied to specific } \\
\text { measurable objectives or targets and thus easier to evaluate, } \\
\text { whereas governmental legislation is on-going and tends to } \\
\text { remain broad in scope. }\end{array}$
\end{tabular} \mid $\mathbf{2 / 1 0}$

Note. C+ grade using the AHK Global Alliance Grading Rubric 


\section{Supplementary Material 1}

\section{Policy Instruments Analysed}

\begin{tabular}{|c|c|}
\hline Sector/ Topic & Title \\
\hline Health & $\begin{array}{l}\text { Fairer Health Outcomes For All: Reducing Inequities in Health } \\
\text { Strategic Action Plan (2011) }\end{array}$ \\
\hline Health & $\begin{array}{l}\text { Start Active, Stay Active: A report on physical activity for health } \\
\text { from the four home countries' Chief Medical Officers (2011) }\end{array}$ \\
\hline Health & Public Health (Wales) Act 2017 \\
\hline Health & Our Healthy Future: Technical working paper (2009) \\
\hline Health \& Sport & Getting Wales Moving (2017) \\
\hline Sport & Climbing Higher (2005) \\
\hline Sport & Creating an Active Wales (2009) \\
\hline Sport & Community Sport Strategy 2012 - 2020 \\
\hline Education & Physical education in the National Curriculum for Wales (2008) \\
\hline $\begin{array}{l}\text { Sport \& } \\
\text { Education }\end{array}$ & $\begin{array}{l}\text { Physical Literacy - an all-Wales approach to increasing levels of } \\
\text { physical activity for children and young people. (2013) }\end{array}$ \\
\hline Transport & Active Travel (Wales) Act 2015 \\
\hline Transport & An Active Travel Action Plan for Wales (2016) \\
\hline Environment & Natural Resources Policy Statement (2015) \\
\hline Planning & Planning (Wales) Act 2015 \\
\hline Planning & Planning Policy Wales (2016) \\
\hline Cross-cutting & Prosperity for All (2017) \\
\hline Play & Welsh Assembly Government Play Policy (2002) \\
\hline Play & Play in Wales: Play Policy Implementation Plan (2006) \\
\hline Play & Children and Families (Wales) Measure 2010 \\
\hline Play & Wales: A Play Friendly Country (2014) \\
\hline $\begin{array}{l}\text { Sustainable } \\
\text { Development }\end{array}$ & The Well-being of Future Generations (Wales) Act 2015 \\
\hline
\end{tabular}




\section{Supplementary Material 2}

\section{National Programmes}

- Change 4 Life Wales - C4L is a UK society-wide movement that aims to prevent people from becoming overweight by encouraging them to eat better and move more. It is the social marketing component of the UK Government's response to the rise in obesity.

- 10 Steps to a Healthy Weight - Welsh public weight management campaign aimed at parents.

- This Girl Can - UK sport campaign aimed at girls and women.

- Dragon multi-skill and sport - Welsh national sport \& physical literacy programme for $7-11 \mathrm{yr}$ olds aimed at parents, teachers and volunteers.

- Physical Literacy, a journey through life - Video aimed at parents and teachers but not well promoted.

- Active Journeys Programme in Wales - Sustrans led active travel programme aimed at schools. Across Wales but limited capacity.

- StreetGames - A UK volunteer led programme focused on local communities.

- Children's Free Swim Programme - A national programme delivering free swimming opportunities through local authority facilities at set times during school holidays.

- Club Solutions (Sport Wales) - Although not directed at solely clubs for children this national program offers guidance, potential funding, and planning steps to help individuals set up sport clubs in their local areas. 